\title{
College-enterprise Cooperation under Interest Demands for Construction Engineering in Higher Vocational College
}

\author{
Xin Liu $^{1 a}$, Xin Wang ${ }^{1 b}$ \\ ${ }^{1}$ Liao Ning Urban Construction Technical College, 110122, China \\ a30154207@qq.com, b236437737@qq.com
}

\begin{abstract}
Keywords: college-enterprise cooperation, construction engineering interest demands, higher vocational education.

Abstract. Higher vocational colleges' College-enterprise cooperation is mostly "one-way-type", only the college struggles, the enterprise participation is not enough and construction engineering is particularly obvious. The premise of college-enterprise is to find common interests under the mode of common interests and start the cooperation, thus the effect of College-enterprise cooperation will be prominent and the quality of talents training will meet the requirements of vocational education.
\end{abstract}

\section{Introduction}

"Long-term Education Reform and Development Plan," 2010 released , noted that Vocational Education requests the combination of work and study, college enterprise cooperation, the mode of talents training of practice, mobilizing the enthusiasm of the industry and enterprise, establishing and improving the government-led industry guidance, enterprise cooperation in the school system, formulating regulations to promote school-enterprise cooperation, promoting institutionalization of college enterprise cooperation. College-enterprise cooperation has become the essential way to pass for higher vocational education reform and development. Currently, vocational college enterprise cooperation is mostly "one-way-type", more is that according to their needs, colleges organize students to corporate internship or work, the enthusiasm of college enterprise cooperation interaction is not high, especially the high risk of construction, objectively increase the difficulty of college enterprise cooperation. College-enterprise cooperation is basically a college-based, supplemented by the nature of the business, the mechanism of scientific and effective cooperation has not yet been formed. Therefore, to explore the motivation of college enterprise cooperation, to combine with the features of construction engineering, to start college enterprise cooperation from the interests of the demands, it is important for improving the quality of talents training in construction engineering and satisfying the demands of construction enterprise and reaching both college and enterprise sustainable and stable development.

\section{Connotation and meaning for college-enterprise cooperation under interest demands}

The base of higher vocational education is employment education. College students who can pass the enterprises' inspection can be called talents. Only when the talent training is planned, organized, inspected and employed by enterprises can students be called technical skill talent. In Canada, as the representative of the CBE (Competency Based Education) with the ability to occupation education standard; The German "dual system"; the Australian TAFE mode, these advanced vocational education modes emphasize government guidance, industry guidance, enterprises participation. A good mode of education and theory, without the participation of enterprises and cooperation, can not meet the requirements of the vocational education.

At the macro level, college-enterprise cooperation emphasizes the thought of doing by a hands $d$ brain and the purpose is to promote the harmonious development of students. At the meson level, college-enterprise cooperation refers to the relationship between the college and the society related 
enterprises, institutions and other departments and the aim is to integrate learning system and labor system and an innovation of educational system. At the micro level, college-enterprise cooperation is a kind of education mode who emphasizes the combination of micro personnel training and practice. No matter what level, a characteristic of college-enterprise cooperation is dual and differences in education. Enterprise is the subject of interest whereas college and government is the public interest. They are parallel in different world, representing different interest subjects. Enterprise is the profit. The basic premise of college-enterprise cooperation is that government and college can create interests for enterprise.

\section{Main responsibility of college-enterprise cooperation}

College education takes place only in the classroom and inner training places. Even creating real working environment, the course system and the working process is simulated. The student environmental experience and psychological feelings has a gap between the actual work sites. Some experience and methods only learned in a real working environment. Cultivation of practical skills in college training base is still far. It is difficult to cultivate qualified technical talents. As to mutually beneficial win-win college-enterprise cooperation principles, it is necessary to explore the long-term cooperation mode with cooperative contents which belong to all-around, whole process, diversified forms and high levels.

It is necessary to develop the role of professional guidance committee composed by cultivation and design higher vocational talent cultivation mode. The mode is the top-level and key to specialized construction. Only with enterprises' creation together can be trained the professional and technical talents to fit and meet the needs of enterprises.

College and enterprises should develop various teaching basic construction for profession and share teaching resources together. On one hand, technical force, training conditions and social influences in college can be used as ascendant resources to be shared with enterprise. On the other hand, enterprise's equipments, advanced production technology and real work environment can be fully participated in each link of teaching to achieve mutual benefit between college and enterprises.

College and enterprises should promote the overall quality of education based on standards of qualified people in society. Student's responsibility is the most important quality in future. It is difficult to become students with the occupation mature of hard working and dedication in college. Thus college teaching should combine its culture and contents with enterprises' culture and vocation qualities.

In order to show the characteristics of vocation education, college and enterprises should mutually promote teaching reform of higher vocational education and the "double certificates" education. Enterprises should participate in various of college teaching reforms actively in case of deviating from the direction. The job skills training and education of qualification certificate should make full use of college resources and advantages to realize mutual win-win.

College should emphasize the training of students' vocational ability. College and enterprises mutually contribute new curriculum of combination of production and academy and organize teachers and students to participate in the production practice. Curriculum is the key to the vocational education and curriculum reform is the priority. The reconstruction of the curriculum content must be fit to the standard of enterprises. Teaching reform is college advantage. College and enterprises should mutually develop the curriculum and complete the production practice and make supplement for each other.

College and enterprises should mutually promote employment of graduates, achieving mutual cooperation, benefits and win-win. Talents cultivated by college meet the needs of the enterprises in order to make students employ. Personnel quality is directly related to the future development of enterprises. The future competition among the enterprises is mainly the competition of talents. This is the most powerful technical support which college provide for enterprises.

College defines the curriculum connotation taking job skill ability as the goal and establishes the curriculum system based on working process. The professional curriculum system should break the 
traditional teaching mode, not only to moderate enough, but also to broaden the overall. Besides emphasizing on professional foundation, the curriculum should strengthen the training of job skill ability and realize that graduates can be employed after graduation and work independently.

College should pay attention to the practice, openness and vocation of teaching process and explore the effective teaching forms, such as task drivers, Project Guide and so on. Then it will find a feasible way of developing curriculum of based on working process and action oriented.

\section{Methods of college-enterprise cooperation in Construction Engineering}

Construction engineering in higher vocational education cultivate high-skilled talents who understand technology, manage and innovate well for the first line of the construction. The construction engineering in Liaoning Urban Construction Technical College has accumulated much experience and certain practices since it found. Such mainly points include the following:

Construction engineering makes full use of resources of construction administrative departments to contact with the construction enterprises, establishing the first step of college-enterprise cooperation according to administrative measures .

College establishes a long-term cooperation relationship with enterprises and contact frequently with deep feelings, cultivating feelings before mutual interests.6. In order to shift the risk, our major creates favorable conditions for students, such as encourage students to buy accidental injury insurance, strengthen safe education among the interns outside the college, and reinforce the practical teaching management to bear collective responsibility with enterprises.

College attaches importance to students and alumni. It is not only a valuable wealth of the college whose graduates with love and dedication to college and enterprises but also a shortcut of college-enterprise cooperation.

College makes use of the public service platform to promote enterprises, especially the propaganda of enterprises' donations and help to college to shape its brand and good image in society and campus. At the same time ,let the enterprises realize the importance of this intangible brand effect.

College should increase and create opportunities of first-line technical staff teaching on campus. At the same time it is necessary to pave the way of enterprises' practice for students and teachers.

In order to shift the risk, our major creates favorable conditions for students, such as encourage students to buy accidental injury insurance, strengthen safe education among the interns outside the college, and reinforce the practical teaching management to bear collective responsibility with enterprises.

In order to solve all kinds of technical problems in production by college-enterprise cooperation, college improves study and conduct professional and technical exchange with enterprises. Now college has established master-level studios in colleges and teachers' studio in enterprises.

Once college wants to correct the professional talent cultivation plan or set up the curricula construction, college must take advices from enterprises. College often invites enterprise personnel to take part in the teaching process and the evaluation so that college could make the teaching contents and the enterprise operation direct butt joint.

\section{Summary}

Above all, the characteristics of Construction Engineering decide the difficulty in college-enterprise cooperation. Unless college carries out college-enterprise cooperation steadily, college can't cultivate talents who fit in with the needs of enterprises. On one hand, modern vocational education should be consistent with the need of personnel of enterprises because enterprises are the supports of vocational education's developments. On the other hand, being the structure of material production, enterprises should be sustained by the power of knowledge and technology correspondingly. Colleges are the intellectual supporting force of enterprises. As the economic development of future 
societies emphasizes common progresses and financial gains, college-enterprise cooperation will be characterized of attachment relationship and loose cooperation transferring the integration relationship. It requires colleges and enterprises become an interest group and form long-term associations relying on their common interests. With this mode of cooperation, colleges will set the long-term interests of enterprises as their fundamental goals, and enterprises will involve in all areas of colleges. For example, enterprises bear functions of talent training and management, etc. by technology and equipment investment in higher vocational colleges and share the educational efficiency accordingly. Such integration relationship can solve a lot of problems such as the contradiction between the limited funds and the unlimited renewal of equipment and technology, the contradiction between the practical teachers' training and the task of teaching and the inactive engagement of enterprises so as to form a mutually beneficial relationship genuinely.

\section{Subject research}

Project supported by the study on the construction shortage of talents' training mode of high-end skills and scheme, special subject of research bases in Liaoning, China (Grant No. JGZXY11036).

\section{References}

[1] Explore the relationship between college and enterprise cooperation in China, based on the change of the relationship between college and enterprise [J]. Communication of Vocational Education, 2010(10), Yingjie Zhang, Han Xu.

[2] HongbingZhai. College-enterprise cooperation, promoting the high quality of students' employment with connotation construction [J]. Journal of Liaoning vocational college, 2013(1).

[3] Xin Lu, Yi Qin, Na Zhao. The thoughts of building College-enterprise cooperation educational management and protection mechanism [J]. Journal of Liaoning vocational college, 2013(3). 